the Dead Sea and of this valley are covered by alluvial deposits. What the thickness of these may be no one knows; nor can the question of the depth to the solid rocks below the alluvial materials be solved except by extensive boring operations. In my opinion the depth is very great; and if this be so, the answer to the question of the reviewer is plain,-at least, this is the only answer I conceive possible.

Duxfaxwaghy, 12 th May, 1886.

Edward Holl.

\title{
THE DEVELOPMENT OF THE NORTH AMERICAN CONTLNENT.
}

Sir.--There are no questions in Geology more important and more fascinating than those of Palæo-geography. All geologists must be grateful to Prof. Hull for the light he has shed upon them. But, also, there are no questions which are more difficult, and the solution of which is more illusory. I would not again trouble you on this subject except to correct what seems to me a grave misconception on the part of Prof. Hull, ${ }^{1}$ which lies at the basis of nearly all the difference $\theta$ between us.

He refers to an ideal section of the Palæozoic rocks on p. 288 of my "Elements of Geology" (being a section from Canada through New York to Pennsylvania), as indicating continued subsidence of sea-bottom and retreat of shore-line northward during the Palæozoic period. This interpretation is the very opposite of that usually given by American geologists. Perhaps the mistake, if it be one, is partly due to bad drawing. In order to bring all the Palæozoic strata within the compass of a small figure, the southward dip is enormously exaggerated. In fact, the strata are nearly level, the average dip being probably not more than 15-20 feet per mile. The successive appearance of younger and younger rocks as we go southward is supposed by all American geologists to indicate a gradual elevation of the Canadian land-mass of that time, and a consequent advance of the shore-line southward with steady increase of land. This is seen at once if the section be drawn with smaller dips and leaving out details (Fig. 1).

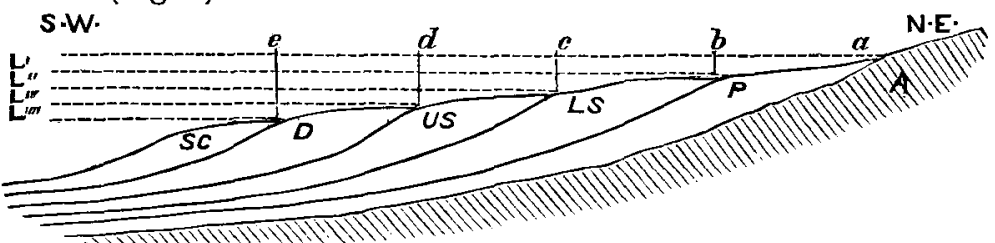

FIG. 1.-Generalized N.E. and S.W. section from Canada through New York to Pennsylvania. A. Archæean. P. Primordial. L.S. Lower Silurian. U.S. Upper Silurian. D. Devonian. S.C. Sub-Carboniferous. a $b c d e$ successive shore-lines. $l l^{\prime} l^{\prime \prime} l^{\prime \prime \prime} l^{\prime \prime \prime \prime}$ successive sea-levels.

The western shore-line of the eastern land-mass was, on the contrary, nearly stationary, and hence the prodigious thickness of Palæozoic sediments in the Appalachian region. Even here, however,

1 See Prof. Hull's letter, GEOL. MAG. April, 1886, p. 189. 
whatever movement of shore-line there was, seems to have been westward with increase of land.

Two other points I briefly touch. Prof. Hull thinks that I do not recognize sufficiently, if at all, his most important point, viz. " the increase of thickness of sediments to the N.E. and E., and their attenuation and replacement by limestone in the opposite direction." If I did not lay stress on this, it was only because I supposed it generally recognized, although Prof. Hull brings it out in a very striking way in his figures. No one has emphasized these facts, and their significance as showing a large land-mass to the north-east and a wide ocean to the south-west, more than I have.'

Again, in my previous communication" I said, "There is no reason why the eastern land-mass, which sufficed to contribute $30,000 \mathrm{ft}$. of Silurian and Devonian sediments, should not have been sufficient to contribute the much smaller amount of Carboniferous sediments." Prof. Hull thinks this a begging of the question at issue. For, says he, "the narrow strip of land allowed by Prof. Le Conte was quite insufficient to produce $30,000 \mathrm{ft}$. of conformable sediments." I can only say in reply that Prof. Hull's map of Silurian times led me astray: for this shows just such a land-mass as I suppose, while his map of Carboniferous times shows a very much greater land-mass. I suppose, now, however, that he imagines this land-mass to have increased on its eastern side through Silurian and Devonian times. If so, it must have increased very rapidly, for the Silurian alone is 20,000 ft. thick in the Appalachian region. Joseph IJE Conte.

\section{PERMANENCE OF CONTINENTS \& OCEAN-BASINS, WITH SPECIAL REFERENCE TO THE FORMATION AND DEVELOPMENT OF THE NORTH AMERICAN CONTINENT. ${ }^{3}$}

Sir,-Will you allow me to make a correction? Prof. Chamberlin has kindly drawn my attention to the fact that in my original communication to you on this subject ${ }^{3} \mathrm{I}$ have misrepresented him, and I wish therefore to acknowledge my error. The map on $p .62$ of Prof. Chamberlin's work on the Geology of Winconsin was not intended, as I supposed, as a map of Archæan areas, but really as a map of land during a portion of Archæan times, viz. (if I understand him) at the beginning of the period of Huronian sedimentation. I was misled by its great resemblance to the usually recognized map of Archæan areas. The confusion of thought to which I referred does indeed exist, but Prof. Chamberlin is not an example of it.

Let us hope that Prof. Chamberlin will give us more fully his mature views on this so olscure and yet so important subject. No one is more competent than he to write with authority on the subject.

Joseph Le Conte.

Berkeley, California, May 3, 1886.

1 Am. Jour, vol. iv. p. 463, 1872. Elements of Geol. p. 289.

2 See Geol. Mag. Miarch, 1886, p. 100.

3 Geol. Mag. 1S86, Dec. III. Vol. III. p. 97. 